\title{
Dietary inclusion effect of yacon, ginger, and blueberry on growth, body composition, and disease resistance of juvenile black rockfish (Sebastes schlegeli) against Vibrio anguillarum
}

\author{
Ki Wook Lee ${ }^{1}$, Hae Seung Jeong ${ }^{2}$ and Sung Hwoan $\mathrm{Cho}^{3^{*}}$
}

\begin{abstract}
Background: To minimize the use of antibiotics and to obtain a more sustainable fish culture and aquaculture industry, development of alternative natural source of immunostimulant to replace antibiotic in aquafeed is highly needed.

Objective: Dietary inclusion effect of yacon (YC), ginger (GG), and blueberry (BB) on growth, body composition, and disease resistance of black rockfish against Vibrio anguillarum was compared to ethoxyquin (EQ).

Methods: Four hundred eighty juvenile (an initial weight of $4.2 \mathrm{~g}$ ) fish were randomly distributed into 12 of $50 \mathrm{~L}$ flowthrough tanks (forty fish per tank). Four experimental diets were prepared; the control (Con) diet with $0.01 \%$ EQ inclusion, and YC, GG, and BB diets at 1\% each additive inclusion. Each additive was included into the experimental diets at the expense of wheat flour. Each diet was assigned to triplicate tanks of fish and hand-fed to satiation twice daily for 8 weeks. At the end of 8-week feeding trial, 20 fish from each tank fish were artificially infected by intraperitoneal injection with $0.1 \mathrm{~mL}$ of culture suspension of pathogenic $V$. anguillarum containing $3.3 \times 10^{6} \mathrm{cfu} / \mathrm{mL}$ respectively. Fish were monitored for the following 8 days after $V$. anguillarum infection and dead fish were removed every $6 \mathrm{~h}$ for the first 4 days and $12 \mathrm{~h}$ for the rest of the study.
\end{abstract}

Results: Weight gain, specific growth rate (SGR), and feed efficiency ratio (FER) of fish fed the YC diet was higher than those of fish fed all other diets. However, feed consumption, protein efficiency ratio, and protein retention was not affected by dietary additive. Moisture, crude protein, and crude lipid content of the whole body of fish were affected by dietary additive. Analysis of the Kaplan-Meier survival curves showed that survival of fish fed the YC, BB, and GG diets was higher than the Con diet.

Conclusion: Oral administration of YC can improve not only weight gain, SGR, and FER of black rockfish, but lower mortality of rockfish at occurrence of $V$. anguillarum.

Keywords: Black rockfish (Sebastes schlegeli), Yacon, Ginger, Blueberry, Vibrio anguillarum

\footnotetext{
* Correspondence: chosunh@kmou.ac.kr

${ }^{3}$ Division of Marine Bioscience, Korea Maritime and Ocean University, Busan

49112, Republic of Korea

Full list of author information is available at the end of the article
}

(c) The Author(s). 2020 Open Access This article is licensed under a Creative Commons Attribution 4.0 International License, which permits use, sharing, adaptation, distribution and reproduction in any medium or format, as long as you give appropriate credit to the original author(s) and the source, provide a link to the Creative Commons licence, and indicate if changes were made. The images or other third party material in this article are included in the article's Creative Commons licence, unless indicated otherwise in a credit line to the material. If material is not included in the article's Creative Commons licence and your intended use is not permitted by statutory regulation or exceeds the permitted use, you will need to obtain permission directly from the copyright holder. To view a copy of this licence, visit http://creativecommons.org/licenses/by/4.0/. 


\section{Background}

Black rockfish (Sebastes schlegeli Hilgendorf 1880) has been one of the most commercially important marine aquaculture fish species in Korea, Japan, and China since over two decades ago due to its fast growth and high resistance against disease. Therefore, many studies to elucidate dietary nutrient requirements (Lee 2001; Lee et al. 2002; Yan et al. 2007), optimum dietary protein to lipid ratio (Cho et al. 2015), alternative animal and/or plant protein sources for fish meal in the diet (Lee et al. 1996; Lim et al. 2004; Jeon et al. 2014), optimum dietary carbohydrate to lipid ratio (Lee and Kim 2009), effect of dietary lipid sources (Aminikhoei et al. 2013), optimum feeding frequency and rate (Lee et al. 2000; Mizanur et al. 2014), and effect of dietary additive to improve lysozyme activity and stress recovery (Hwang et al. 2013), and immune response against Vibrio alginolyticus (Kim et al. 1999) and Vibrio ordalii (Lim et al. 2009) infection for black rockfish have been reported.

Application of antibiotics has been widespread to reduce mortality during year-round fish culture. As oral administration of synthetic antibiotic in aquafeed, however, is prohibited in some countries (Tang et al. 2001) due to high possibility of contamination of environment and culturing fish used for human consumption (Alderman and Hastings 1998), development of the new natural source of dietary additive that has no side effect on environment and culturing fish to replace synthetic antibiotics keeps being needed.

Vibriosis is a major disease occurring in marine and brackish water fish and characterized by hemorrhagic septicemia (Demircan and Candan 2006). Vibrio spp. has been one of main pathogens causing high mortality occurred in marine fish including olive flounder Paralichthys olivaceus, black rockfish, and red sea bream Pagrus major and shrimp farm during summer season year after year in Korea (Choi et al. 2010a; Jung et al. 2012). Therefore, development of new natural source of dietary additive to lower mortality of fish at occurrence of $V$. anguillarum is highly desired.

Yacon Polymnia sonchifolia Poeppig and Endlicher (YC) containing the polyphenols had an antioxidant activity (Park et al. 2012). Its leaves showed the antibacterial activity against Staphylococcus aureus (Choi et al. 2010b). In our early study, YC was the most effective additive to improve weight gain and feed utilization of black rockfish among the several feed additives tested (Kim et al. 2016).

Ginger Zingiber officinale Roscoe (GG) containing gingerols and shogaols is known to have antibacterial properties (Ekwenye and Elegalam 2005; Sebiomo et al. 2011) and antioxidant activity (Balestra et al. 2011). Akintobi et al. (2013) reported that water and ethanol extracts of GG showed the highest inhibition against Salmonella typhi and Proteus mirabilis, respectively and postulated that the extracts of GG possessed antimicrobial compounds, which could be used as substitutes for the antibiotics. In addition, oral administration GG effectively improved weight gain and disease resistance of several fish (Nya and Austin 2009; Talpur et al. 2013; Hassanin et al. 2014).

Blueberry Vaccinium ashei Reade (BB) containing anthocyanin had an antioxidant activity (Vizzotto et al. 2013; Deng et al. 2014) and showed antioxidant effect on animals (Molan et al. 2008; Papandreou et al. 2009).

Ethoxyquin (EQ) is the most widely used as a synthetic antioxidant in fish feed to prevent rancidity (Weil et al. 1968; FAO 1970; Thorisson et al. 1992; Drewhurst 1998). The optimal EQ concentrations of 13.8 and $50 \mathrm{mg} / \mathrm{kg}$ diet were reported for Japanese sea bass Lateolabrax japonicus and large yellow croaker Pseudosciaena crocea, respectively (Wang et al. 2010, 2015). The upper limit for EQ in fish feed established in the EU is $150 \mathrm{mg} / \mathrm{kg}$ diet (Council Directive 2003). In addition, Bohne et al. (2007) proposed that EQ-derived residues in salmon might have high toxicological effects for human consumers.

The widespread use of antibiotics should be minimized because it causes antibiotic contamination of the environment and fish used for human consumption (Alderman and Hastings 1998) as well as leading to the development of antibiotic resistance. For instance, Colquhoun et al. (2007) observed oxolinic acid resistance among $V$. anguillarum strains isolated from diseased Atlantic cod Gadus morhua. In spite of these drawbacks, antimicrobial therapy is still required for containment of vibriosis outbreaks. To minimize the use of antibiotics and to obtain a more sustainable fish culture and aquaculture industry, development of alternative natural source of immunostimulant to replace antibiotic in aquafeed is highly needed.

Those natural sources (YC, GG, and $\mathrm{BB}$ ) of plantoriginated ingredients have high potential as an alternative antibiotic in rockfish feed when fish were fed with one of the diets containing various sources of additives for 7 weeks, and then infected with Strepotococcus parauberis (Kim et al. 2016). The other plant-originated additives were also effective to improve not only weight gain and feed utilization, but also disease resistance in some marine fish (Ji et al. 2007a; Punitha et al. 2008; Talpur and Ikhwanuddin 2012; Talpur et al. 2013; Talpur 2014).

Therefore, the effect of dietary inclusion of YC, GG, and $\mathrm{BB}$ on growth, body composition, and disease resistance of juvenile black rockfish against $V$. anguillarum was compared to EQ in this study.

\section{Methods}

Fish and the experimental conditions

Juvenile black rockfish were purchased from a private hatchery (Tongyeong City, Gyeongsangnam-do, Korea) and acclimated to the experimental conditions for 2 
weeks before an initiation of the feeding trial. During the acclimation period, fish were hand-fed a commercial extruded pellet (Suhyup Feed Co. Ltd., Gyeongsangnmado, Korea) twice a day at a ratio of $2-3 \%$ body weight of fish. Four hundred eighty juvenile fish (an initial body weight of $4.2 \mathrm{~g}$ ) were randomly chosen and distributed into 12 of $50 \mathrm{~L}$ flow-through tanks (water volume: $40 \mathrm{~L}$ ) (40 fish per tank). The flow rate of water into each tank was $1.41 \mathrm{~L} / \mathrm{min} / \operatorname{tank}$. The water source was sand-filtered natural seawater and aeration was supplied into each tank. Water temperature monitored daily from 17.4 to $23.9{ }^{\circ} \mathrm{C}$ (mean \pm SD: $20.1 \pm 3.23{ }^{\circ} \mathrm{C}$ ) and photoperiod followed natural conditions.

\section{Preparation of the experimental diets}

Four experimental diets were prepared; the control (Con) diet with $0.01 \%$ EQ inclusion, and YC, GG, and $\mathrm{BB}$ diets at $1 \%$ each additive inclusion (Table 1). Each additive, which is a commercially available product (Tojongherb Co Ltd., Seoul, Korea), was included into the experimental diets at the expense of wheat flour. The Con diet was prepared to satisfy dietary nutrient requirements for black rockfish (Kim et al. 2001; Kim et al. 2004). Fish meal and fermented soybean meal were used as the protein source in the experimental diets. Wheat flour, and squid liver and soybean oils were used as the carbohydrate and lipid sources, respectively in the experimental diets.

The ingredients of the experimental diets were well mixed with water at a ratio of 3:1 and pelletized by lab pellet-extruder (Dongsung mechanics, Busan, Korea). The experimental diets were dried at room temperature overnight and stored in $-20{ }^{\circ} \mathrm{C}$ until used. Each diet was randomly assigned to triplicate tanks of fish and handfed to satiation twice daily (07:00 and 17:00 h) for 7 day a week for 8 weeks. Tanks were siphon-cleaned daily.

\section{Analytical procedures of the experimental diets and fish}

Ten fish at the start and seven fish from each tank at the termination of the feeding trial were sampled and sacrificed for proximate analysis. Crude protein was determined by the Kjeldahl method (Kjeltec 2100 Distillation Unit, Foss Tecator, Hoganas, Sweden), crude lipid was determined using an ether-extraction method (Soxtec TM 2043 Fat Extraction System, Foss Tecator, Sweden), moisture was determined by oven drying at $105{ }^{\circ} \mathrm{C}$ for $24 \mathrm{~h}$, fiber was determined using an automatic analyzer (Fibertec, Tecator, Sweden), and ash was determined using a muffle furnace at $550{ }^{\circ} \mathrm{C}$ for $4 \mathrm{~h}$.

\section{Serum chemistry of fish}

Blood samples were obtained from the caudal vein of five randomly chosen fish from each tank by using syringes after they were starved for $24 \mathrm{~h}$. Serum was collected
Table 1 Ingredients of the experimental diets containing the various sources of additives (DM basis, \%)

\begin{tabular}{|c|c|c|c|c|}
\hline & \multicolumn{4}{|c|}{ Experimental diets } \\
\hline & Con & $Y C^{a}$ & $\mathrm{GG}^{\mathrm{a}}$ & $\mathrm{BB}^{\mathrm{a}}$ \\
\hline \multicolumn{5}{|l|}{ Ingredients (\%) } \\
\hline Fish meal ${ }^{b}$ & 63.5 & 63.5 & 63.5 & 63.5 \\
\hline Fermented soybean meal ${ }^{c}$ & 7.0 & 7.0 & 7.0 & 7.0 \\
\hline Wheat flour & 22.99 & 22.0 & 22.0 & 22.0 \\
\hline Ethoxyquin ${ }^{d}$ & 0.01 & & & \\
\hline Additives & & 1 & 1 & 1 \\
\hline Squid liver oil & 2.0 & 2.0 & 2.0 & 2.0 \\
\hline Soybean oil & 2.0 & 2.0 & 2.0 & 2.0 \\
\hline Vitamin premix & 1.0 & 1.0 & 1.0 & 1.0 \\
\hline Mineral premix & 1.0 & 1.0 & 1.0 & 1.0 \\
\hline Choline & 0.5 & 0.5 & 0.5 & 0.5 \\
\hline \multicolumn{5}{|l|}{ Nutrients (\%) } \\
\hline Dry matter & 90.7 & 90.5 & 91.1 & 91.0 \\
\hline Crude protein & 50.4 & 50.8 & 50.2 & 50.1 \\
\hline Crude lipid & 10.8 & 10.9 & 11.2 & 11.0 \\
\hline Ash & 10.1 & 10.2 & 10.2 & 10.5 \\
\hline
\end{tabular}

${ }^{a} Y C$ (yacon), GG (ginger), and BB (blueberry) powder were purchased from Tojongherb Co Ltd. (Dongdaemun-gu, Seoul, Korea)

${ }^{\mathrm{b}}$ Fish meal and was purchased from Abank Co Ltd. (Seocho-gu, Seoul, Korea) ${ }^{\mathrm{c}}$ Fermented soybean meal was supplied by CJ CheilJedang Corp. (Jung-gu, Seoul, Korea)

dEthoxyquin was supplied from Chunhajeil feed Co Ltd. (Daedeok-gu, Daejeon, Korea)

'Vitamin premix contained the following amount which were diluted in cellulose (g/kg mix): L-ascorbic acid, 121.2; DL-a-tocopheryl acetate, 18.8; thiamin hydrochloride, 2.7; riboflavin, 9.1; pyridoxine hydrochloride, 1.8; niacin, 36.4; Ca-D-pantothenate, 12.7; myo-inositol, 181.8; D-biotin, 0.27; folic acid, 0.68; p-aminobenzoic acid, 18.2; menadione, 1.8; retinyl acetate, 0.73 ;

cholecalciferol, 0.003; cyanocobalamin, 0.003

${ }^{\mathrm{f}}$ Mineral premix contained the following ingredients ( $\left./ \mathrm{kg} \mathrm{mix}\right): \mathrm{MgSO}_{4} \cdot 7 \mathrm{H}_{2} \mathrm{O}$, 80.0; $\mathrm{NaH}_{2} \mathrm{PO}_{4} \cdot 2 \mathrm{H}_{2} \mathrm{O}, 370.0 ; \mathrm{KCl}, 130.0$; ferric citrate, 40.0; $\mathrm{ZnSO}_{4} \cdot 7 \mathrm{H}_{2} \mathrm{O}, 20.0$; Calactate, 356.5; CuCl, 0.2; $\mathrm{AlCl}_{3} \cdot 6 \mathrm{H}_{2} \mathrm{O}, 0.15 ; \mathrm{Kl}, 0.15 ; \mathrm{Na}_{2} \mathrm{Se}_{2} \mathrm{O}_{3}, 0.01 ; \mathrm{MnSO}_{4} \cdot \mathrm{H}_{2} \mathrm{O}$, 2.0; $\mathrm{CoCl}_{2} \cdot 6 \mathrm{H}_{2} \mathrm{O}, 1.0$.

after centrifugation (900 $\mathrm{g}$ for $10 \mathrm{~min}$ ); stored in the freezer at $-70{ }^{\circ} \mathrm{C}$ as separate aliquots for analysis of total protein, total cholesterol, glutamate oxaloacetate transaminase (GOT), glutamate pyruvate transaminase (GPT), and triglyceride; and analyzed by using automatic chemistry system (HITACHI 7180/7600-210, Hitachi, Japan).

\section{Challenge test}

Twenty externally normal fish shown to be free from bacterial infection were selected from each tank and stocked into 12, static $50 \mathrm{~L}$ tanks at the end of the 8week feeding trial. Fish was used for the $V$. anguillarum challenge and water was not exchanged. The bacteria used for the challenge were reference pathogenic strain of gram-negative $V$. anguillarum (FP2247) isolated from black rockfish.

The culture suspension of $V$. anguillarum were grown on agar for $24 \mathrm{~h}$, collected, washed, and suspended in 
sterile $0.85 \%$ saline solution and counted. Then, fish were artificially infected by intraperitoneal injection with $0.1 \mathrm{~mL}$ of culture suspension of pathogenic $V$. anguillarum containing $3.3 \times 10^{6} \mathrm{cfu} / \mathrm{mL}$ respectively. Fish were monitored for the following 8 days after $V$. anguillarum infection and dead fish were removed every $6 \mathrm{~h}$ for the first 4 days and $12 \mathrm{~h}$ for the rest of the study. Fish was starved throughout the 8-day challenge test.

\section{Calculations and statistical analysis}

The following variables were calculated: specific growth rate $(\mathrm{SGR}, \% /$ day $)=(\mathrm{Ln}$ final weight of fish $-\mathrm{Ln}$ initial weight of fish) $\times 100 /$ days of feeding trial, feed efficiency ratio $($ FER $)=$ weight gain/feed consumed, protein efficiency ratio (PER) = weight gain of fish/protein consumed and protein retention $(\mathrm{PR})=$ protein gain $\times 100 /$ protein consumed .

SAS version 9.3 (SAS Institute, Cary, NC, USA) was used to conduct a one-way ANOVA. Tukey's honestly significant difference (HSD) test was used to determine the significance $(P<0.05)$ of the differences among the means responses to dietary treatments. Percentage data was arcsine-transformed prior to statistical analysis. The survival patterns were analyzed using Kaplan-Meier survival curves, Log-rank and Wilcoxon tests.

\section{Results}

\section{Growth performance of black rockfish}

No significant difference in survival of black rockfish was observed at the end of the 8-week feeding trial (Table 2). However, weight and SGR of fish fed the YC diet were significantly higher than those of fish fed all other (GG, BB, and Con) diets. Weight gain and SGR of fish fed the GG and BB diets were also significantly $(P<$ 0.05) higher than those of fish fed the Con diet.

\section{Feed utilization}

Feed consumption (g/fish) of fish was not significantly affected by dietary additive (Table 3). FER of fish fed the $\mathrm{YC}$ diet was significantly higher than that of fish fed the all other diets. No significant difference in FER was observed among fish fed the Con, GG, and BB diets. PER of fish was not significantly affected by dietary additive.
PR of fish fed the YC and GG diets was significantly higher than that of fish fed the Con and BB diets.

\section{Chemical composition of the whole body of fish}

Moisture content of the whole body of fish fed the BB diet was significantly higher than that of fish fed the all other diets (Table 4). Moisture content of the whole body of fish fed the Con diet was also significantly higher than of fish fed the YC and GG diets. Crude protein content of the whole body of fish fed the GG diet was significantly higher than that of fish fed the all other diets, followed by the YC, Con, and BB diets. Crude lipid content of the whole body of fish fed the YC and GG diets was significantly higher than that of fish fed the Con and $\mathrm{BB}$ diets. Ash content of the whole body of fish was not significantly affected by dietary additive.

\section{Plasma chemistry of fish}

Plasma chemistry (total protein, total cholesterol, GOT, GPT, and triglycerides) of fish was not significantly affected by dietary additive (Table 5).

\section{Challenge test}

Survival of fish fed the experimental diets containing various sources of additive for 8 weeks, and then infected with $V$. anguillarum for 8-day post observation is depicted in Fig. 1. Analysis of the Kaplan-Meier survival curves showed that the survival of black rockfish fed the YC $(51.7 \pm 0.02 \%$; means of triplicate $\pm \mathrm{SE}), \mathrm{BB}(46.7 \pm 0.02 \%)$, and GG (26.7 \pm $0.02 \%$ ) diets was significantly higher than that of fish fed the Con $(1.7 \pm 0.02 \%)$ diet. In addition, the survival of fish fed the $\mathrm{YC}$ and $\mathrm{BB}$ diets was also significantly higher than that of fish fed the GG diet.

\section{Discussion}

Oral administration of feed additives (YC, GG, and BB) used in this study achieved improved weight gain of black rockfish compared to the Con diet. The greatest improvement in weight gain, SGR and FER was obtained in fish fed the YC diet agreed with Kim et al. (2016)'s study showing that $\mathrm{YC}$ was the most effective additive to improve growth performance and FER of black rockfish. Improved weight gain, SGR and PR of fish fed the GG

Table 2 Survival (\%), weight gain (g/fish) and specific growth rate (SGR, \%/day) of black rockfish Sebastes schlegeli fed the experimental diets containing the various sources of additives for 8 weeks

\begin{tabular}{|c|c|c|c|c|c|}
\hline Experimental diets & Initial weight (g/fish) & Final weight (g/fish) & Survival (\%) & Weight gain (g/fish) & $\begin{array}{l}\text { SGR } \\
\text { (\%/day) }\end{array}$ \\
\hline Con & $4.3 \pm 0.00$ & $16.4 \pm 0.03$ & $100.0 \pm 0.00^{a}$ & $12.1 \pm 0.03^{c}$ & $2.41 \pm 0.002^{c}$ \\
\hline YC & $4.2 \pm 0.01$ & $16.7 \pm 0.01$ & $100.0 \pm 0.00^{a}$ & $12.5 \pm 0.01^{\mathrm{a}}$ & $2.45 \pm 0.003^{a}$ \\
\hline GG & $4.2 \pm 0.01$ & $16.5 \pm 0.06$ & $100.0 \pm 0.00^{a}$ & $12.3 \pm 0.06^{b}$ & $2.43 \pm 0.006^{b}$ \\
\hline BB & $4.3 \pm 0.00$ & $16.6 \pm 0.03$ & $100.0 \pm 0.00^{\mathrm{a}}$ & $12.3 \pm 0.03^{b}$ & $2.43 \pm 0.002^{b}$ \\
\hline
\end{tabular}

Values (means of triplicates $\pm \mathrm{SE}$ ) in the same column sharing the same superscript letter are not significantly different $(P>0.05)$

${ }^{1} \mathrm{SGR}(\% /$ day $)=($ Ln final weight of fish - Ln initial weight of fish $) \times 100 /$ days of feeding trial 
Table 3 Feed consumption (g/fish), feed efficiency ratio (FER), protein efficiency ratio (PER), and protein retention (PR) of black rockfish (Sebastes schlegeli) fed the experimental diets containing the various sources of additives for 8 weeks

\begin{tabular}{lllll}
\hline Experimental diets & Feed consumption (g/fish) & FER $^{1}$ & PER $^{2}$ & PR $^{3}$ \\
\hline Con & $11.5 \pm 0.03^{\mathrm{a}}$ & $1.06 \pm 0.003^{\mathrm{b}}$ & $2.10 \pm 0.006^{\mathrm{a}}$ & $36.3 \pm 0.19^{\mathrm{b}}$ \\
YC & $11.5 \pm 0.03^{\mathrm{a}}$ & $1.08 \pm 0.003^{\mathrm{a}}$ & $2.13 \pm 0.006^{\mathrm{a}}$ & $37.7 \pm 0.10^{\mathrm{a}}$ \\
GG & $11.5 \pm 0.05^{\mathrm{a}}$ & $1.07 \pm 0.008^{\mathrm{b}}$ & $2.12 \pm 0.017^{\mathrm{a}}$ & $38.2 \pm 0.35^{\mathrm{a}}$ \\
BB & $11.6 \pm 0.07^{\mathrm{a}}$ & $1.06 \pm 0.004^{\mathrm{b}}$ & $2.12 \pm 0.009^{\mathrm{a}}$ & $35.7 \pm 0.24^{\mathrm{b}}$
\end{tabular}

Values (means of triplicate $\pm \mathrm{SE}$ ) in the same column sharing the same superscript letter are not significantly different $(P>0.05)$

${ }^{1}$ Feed efficiency ratio $(F E R)=$ Weight gain of fish/feed consumed

${ }^{2}$ Protein efficiency ratio $(\mathrm{PER})=$ Weight gain of fish/protein consumed

${ }^{3}$ Protein retention $(P R)=$ Protein gain $\times 100 /$ protein consumed

diet compared to the Con diet in this study partially coincided with other studies (Nya and Austin 2009; Talpur et al. 2013; Hassanin et al. 2014) showing that weight gain and feed utilization (FER or PER) of rainbow trout Oncorhynchus mykiss, Asian sea bass Lates calcarifer, and Nile tilapia Oreochromis niloticus improved effectively when $0.1-1 \%$ GG was included in diets. Similarly, dietary inclusion of $0.5 \%$ Chlorella powder and Lycium chinense improved weight gain and FER of black rockfish (Bai et al. 2001; Lim et al. 2009). Gabor et al. (2010) reviewed the use of phytoadditives, such as garlic Allium sativum, onion Allium cepa, oregano Origanum vulgare, GG Echinacea Echinadea purpurea, cinnamon Cinnamomum verum, or nettle Urtica dioica in diets for growth performance of several fish and emphasized the major advantages in the use of phytoadditives is the fact that they are natural substances and do not pose any threat to fish, man, or environment. Therefore, those phytoadditives can be considered as alternative antibiotics in fish feed without serious concern of either fishconsumer or undesirable effect on environment.

The chemical composition of the whole body black rockfish, except for ash content, was affected by dietary additives in this study. A similar result showing that dietary additive affected the whole body composition of black rockfish was reported (Bai et al. 2001; Yun et al. 2016). Moisture content seemed to be reversely related to crude protein and lipid contents of the whole body of rockfish in this study. Unlike this study, however, the chemical composition of the whole body, muscle, viscera, and liver of rockfish was not affected by dietary inclusion of herb medicine mixture of Artemisia asiatica and Epimedium koreanum (Seo et al. 2009).
Plasma criteria (total protein, total cholesterol, GOT, GPT, and triglycerides) of fish measured in this study was not affected by the experimental diets due to wide variation in plasma values within the same treatment.

The dead black rockfish in 8-day post observation after $V$. anguillarum infection in this study exhibited the typical symptoms of diseased fish infected with $V$. anguillarum, such as exophthalmos, externally hemorrhages at the base of pectoral fins, on lateral line, around eyes and around the anal region, darkening of the skin, and swelling of abdomen with accumulation of ascites reported by Kent and Poppe (2002), Li et al. (2005), and Demircan and Candan (2006)'s studies.

Lower mortality (48.3, 53.3, and 73.3\%) of black rockfish fed the YC, BB, and GG diets compared to the Con diet $(98.3 \%)$ at the end of 8-day post observation indicated that $\mathrm{YC}, \mathrm{BB}$, and GG were all effective, especially $\mathrm{YC}$ was the most effective feed additive to lower mortality of rockfish at occurrence of $V$. anguillarum. Outstanding improvement in disease resistance against $V$. anguillarum of black rockfish fed the YC diet in this study indicated that $\mathrm{YC}$ was the most effective immunostimulant for rockfish. Comparison of administration of YC, GG, and BB of olive flounder with commercial immunostimulant (probiotics) or antibiotics against disease resistance is needed in the future.

Similarly, oral administration of YC, BB, and GG for 7 weeks lowered mortality of black rockfish when fish were infected with Streptococcus parauberis (Kim et al. 2016). Dietary inclusion of GG effectively improved disease resistance of rainbow trout against Aeromonas hydrophila, Asian seabass against $V$. harveyi, and Nile tilapia against $A$. hydrophila infections, respectively (Nya and Austin 2009; Talpur et al.

Table 4 Proximate composition (\%) of the whole body of juvenile black rockfish Sebastes schlegeli fed the experimental diets containing the various sources of additives

\begin{tabular}{lllll}
\hline Experimental diets & Moisture & Crude protein & Crude lipid & Ash \\
\hline Con & $69.4 \pm 0.23^{\mathrm{b}}$ & $17.3 \pm 0.03^{\mathrm{c}}$ & $8.0 \pm 0.06^{\mathrm{b}}$ & $5.1 \pm 0.03^{\mathrm{a}}$ \\
YC & $68.2 \pm 0.03^{\mathrm{c}}$ & $17.6 \pm 0.00^{\mathrm{b}}$ & $8.2 \pm 0.03^{\mathrm{a}}$ & $5.0 \pm 0.06^{\mathrm{a}}$ \\
GG & $68.2 \pm 0.03^{\mathrm{c}}$ & $17.8 \pm 0.03^{\mathrm{a}}$ & $8.2 \pm 0.03^{\mathrm{a}}$ & $5.1 \pm 0.03^{\mathrm{a}}$ \\
BB & $70.0 \pm 0.03^{\mathrm{a}}$ & $16.9 \pm 0.21^{\mathrm{d}}$ & $7.8 \pm 0.03^{\mathrm{c}}$ & $5.1 \pm 0.00^{\mathrm{a}}$ \\
\hline
\end{tabular}

Values (means of triplicate $\pm \mathrm{SE}$ ) in the same column sharing the same superscript letter are not significantly different $(P>0.05)$ 
Table 5 Plasma chemistry of black rockfish Sebastes schlegeli at the end of the 8 weeks feeding trial

\begin{tabular}{llllll}
\hline $\begin{array}{l}\text { Experimental } \\
\text { diets }\end{array}$ & Total protein $(\mathrm{g} / \mathrm{dL})$ & Total cholesterol $(\mathrm{mg} / \mathrm{dL})$ & GOT (IU/L) & GPT (IU/L) & Triglyceride (mg/dL) \\
\hline Con & $4.2 \pm 0.02^{\mathrm{a}}$ & $203.0 \pm 5.86^{\mathrm{a}}$ & $64.0 \pm 5.51^{\mathrm{a}}$ & $1.0 \pm 0.00^{\mathrm{a}}$ & $269.0 \pm 8.33^{\mathrm{a}}$ \\
YC & $4.3 \pm 0.34^{\mathrm{a}}$ & $217.7 \pm 18.81^{\mathrm{a}}$ & $57.7 \pm 1.76^{\mathrm{a}}$ & $1.7 \pm 0.33^{\mathrm{a}}$ & $306.0 \pm 14.36^{\mathrm{a}}$ \\
GG & $4.4 \pm 0.08^{\mathrm{a}}$ & $217.0 \pm 6.24^{\mathrm{a}}$ & $57.0 \pm 9.24^{\mathrm{a}}$ & $2.7 \pm 0.67^{\mathrm{a}}$ & $287.3 \pm 20.12^{\mathrm{a}}$ \\
BB & $4.4 \pm 0.18^{\mathrm{a}}$ & $218.0 \pm 12.17^{\mathrm{a}}$ & $61.7 \pm 6.12^{\mathrm{a}}$ & $2.3 \pm 0.33^{\mathrm{a}}$ & $293.0 \pm 16.09^{\mathrm{a}}$ \\
\hline
\end{tabular}

Values (means of triplicate $\pm \mathrm{SE}$ ) in the same column sharing the same superscript letter are not significantly different $(P>0.05)$

2013; Hassanin et al. 2014). Akintobi et al. (2013) showed that high antimicrobial activity of GG extract against six pathogenic microorganisms, such as Pseudomonas aeruginosa, Staphylococcus aureus, Proteus mirabilis, Escherichia coli, Bacillus subtilis, and Salmonella typhi in vitro test and explained that GG can be used as substitute for antibiotics. Lower mortality (48.3 and 53.3\%) of black rockfish fed the $\mathrm{YC}$ and $\mathrm{BB}$ diets compared to the GG diet (73.3\%) at the end of 8-day post observation also indicated that $\mathrm{YC}$ and $\mathrm{BB}$ were also more effective than GG to lower mortality of rockfish at occurrence of $V$. anguillarum. In considering Kim et al. (2016)'s study showing that YC, GG, and BB were effective to lower mortality of black rockfish at occurrence $S$. parauberis and this study, they are all effective as an immunostimulant for both bacterial gram-negative and grampositive pathogens. Vallejos-Vidal et al. (2016) reviewed several plants, herbs, algae extracts, and pathogen associated molecular patterns as immunostimulants in aquafeeds.
The plant-originated additives were effective to improve disease resistance in some marine fish (Sivaram et al. 2004; Ji et al. 2007a; Punitha et al. 2008; Kim et al. 2012; Talpur and Ikhwanuddin 2012; Talpur et al. 2013; Talpur 2014). Ji et al. (2007b) also reported that dietary inclusion of mixture herb of Massa medicate fermentata, Crataegi fructus, Artemisia capillaries, and Cnidium officinale at a ratio of 2:2:1:1 at the concentration $0.3,0.5$, and $1 \%$ improved not only weight gain and FER including fatty acid utilization, but also stress recovery of olive flounder against air exposure and anesthetizing test compared to the control diet without any additive or $0.1 \%$ mixture inclusion diet.

\section{Conclusions}

Oral administration of YC can improve not only weight gain, SGR, and FER of black rockfish, but lower mortality of rockfish at occurrence of $V$. anguillarum.

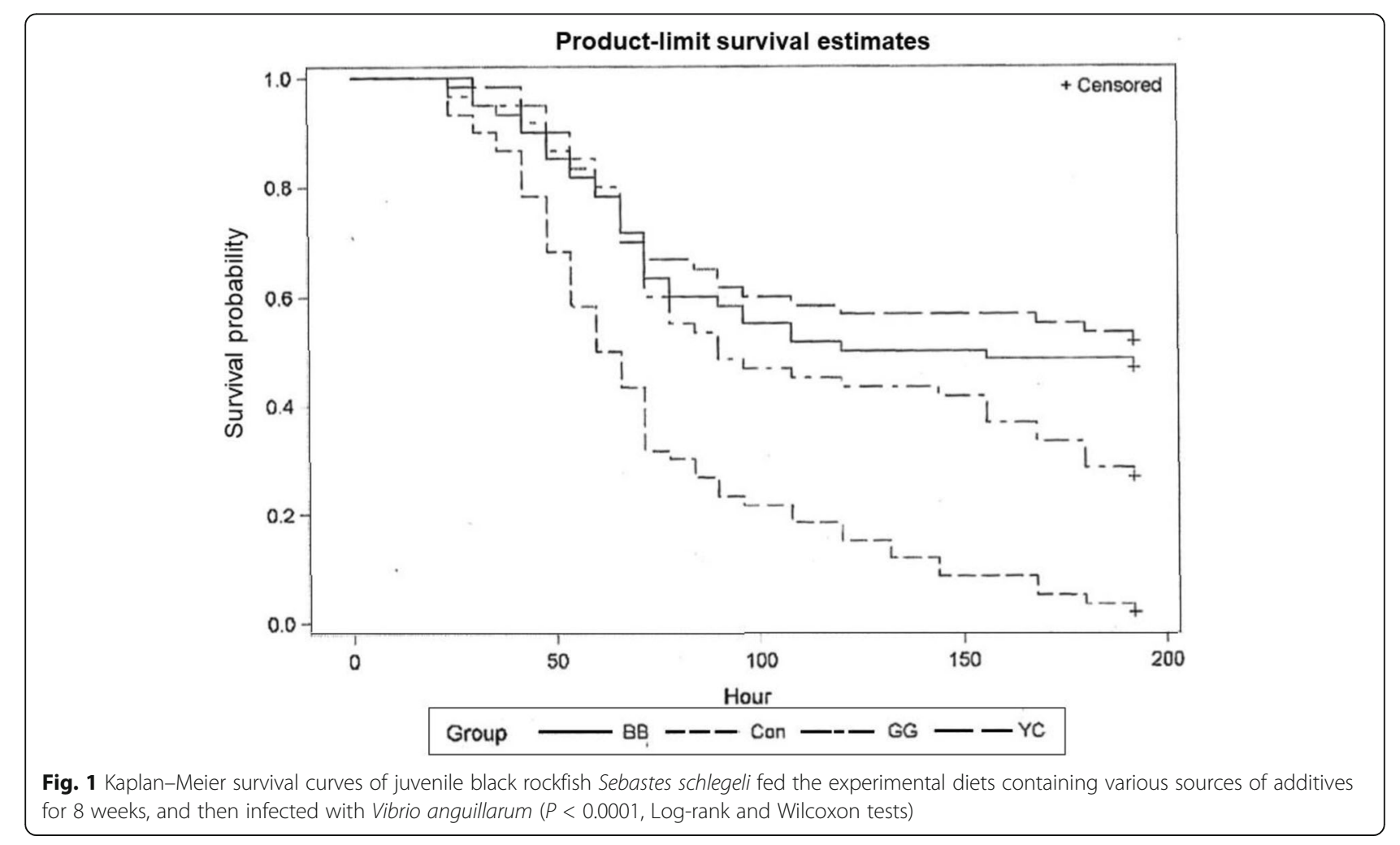




\section{Abbreviations}

YC: Yacon; GG: Ginger; BB: Blueberry; EQ: Ethoxyquin; SGR: Specific growth rate; FER: Feed efficiency ratio; PER: Protein efficiency ratio; PR: Protein retention; GOT: Glutamic oxaloacetic transaminase; GPT: Glutamic pyruvic transaminase

\section{Acknowledgments}

This research was supported by Basic Science Research Program through the National Research Foundation of Korea (NRF) funded by the Ministry of Science, ICT \& Future Planning (2017R1A2B4009773).

\section{Authors' contributions}

SHC designed the study and prepared the draft. KWL and HSJ ran the feeding trial and analyzed the chemical composition of the diets and fish. All authors read and approved the final manuscript.

\section{Funding}

The design of the study, collection, analysis, and interpretation of the data and writing of the manuscript were supported by Basic Science Research Program through the National Research Foundation of Korea (NRF) funded by the Ministry of Science, ICT \& Future Planning (2017R1A2B4009773).

\section{Availability of data and materials}

All datasets generated during and/or analyzed during the current study are available from the corresponding author on reasonable request.

\section{Ethics approva}

All experimental protocols followed the guidelines of the Institutional Animal Care and Use by Committee of the Korea Maritime and Ocean University.

\section{Consent for publication}

Not applicable.

\section{Competing interests}

The authors declare that they have no competing interests.

\section{Author details}

${ }^{1}$ East Sea Fisheries Research Institute, National Institute of Fisheries Science, Gangwon-do 25435, Republic of Korea. ${ }^{2}$ Department of Convergence Study on the Ocean Science and Technology, Korea Maritime and Ocean University, Busan 49112, Republic of Korea. ${ }^{3}$ Division of Marine Bioscience, Korea Maritime and Ocean University, Busan 49112, Republic of Korea.

\section{Received: 27 November 2019 Accepted: 10 March 2020}

\section{Published online: 14 April 2020}

\section{References}

Akintobi OA, Onoh CC, Ogele JO, Idowu AA, Ojo OV, Okonko IO. Antimicrobial activity of Zingiber officinale (ginger) extract against some selected pathogenic bacteria. Nat Sci. 2013;11:7-15.

Alderman DJ, Hastings TS. Antibiotic use in aquaculture: development of resistancepotential for consumer health risks. Int J Food Sci Technol. 1998:33:139-55.

Aminikhoei A, Choi J, Lee S, Kim K. Effects of different dietary lipid sources on growth performance, fatty acid composition, and antioxidant enzyme activity of juvenile rockfish. Sebastes schlegeli. J World Aquac Soc. 2013;44:716-25.

Bai SC, Koo J, Kim K, Kim S. Effects of Chlorella powder as a feed additive on growth performance in juvenile Korean rockfish, Sebastes schlegeli (Hilgendorf). Aquacult Res. 2001;32:92-8.

Balestra F, Cocci E, Pinnavaia G, Romani S. Evaluation of antioxidant, rheological and sensorial properties of wheat flour dough and bread containing ginger powder. LWT. 2011:44:700-5.

Bohne VJB, Hamre K, Arukwe A. Hepatic metabolism, phase I and II biotransformation enzymes in Atlantic salmon (Salmo salar, L) during a 12 week feeding period with graded levels of the synthetic antioxidant, ethoxyquin. Food Chem Toxicol. 2007;45:733-46.

Cho SH, Kim HS, Myung SH, Jung W, Choi J, Lee S. Optimum dietary protein and lipid levels for juvenile rockfish (Sebastes schlegeli, Hilgendorf 1880). Aquacult Res. 2015:46:2954-61.

Choi HS, Jee B, Cho MY, Park M. Monitoring of pathogens on the cultured Korean rockfish Sebastes schlegeli in the marine cages farms of south sea area from 2006 to 2008. J Fish Pathol. 2010a;23:27-35.
Choi JG, Kang OH, Lee YS, Oh YC, Chae HS, Obiang-Obounou B, Kwon DY. Antimicrobial activity of the constituents of Smallanthus sonchifolius leaves against methicillin-resistant Staphylococcus aureus. Eur Rev Med Pharmacol Sci. 2010b;14:1005-9.

Colquhoun DJ, Aarflot L, Melvold CF. gyrA and parC mutations and associated quinolone resistance in Vibrio anguillarum serotype $\mathrm{O} 2 \mathrm{~b}$ strains isolated from farmed Atlantic cod (Gadus morhua) in Norway. Antimicrob Agents Chemother. 2007:51:2597-9.

Council Directive. 70/524/EEC of 23 November 1970 concerning additives in feeding stuffs. Official Journal of the European Communities (L70) of 14 December 1970, pp. 1-17. No longer in force, substituted by Regulation (EC) No. 1831/2003 of the European Parliament and the council of 22 September 2003 on additives for use in animal nutrition. Official Journal of the European Union L268 of 18 October 2003, p. 29-43.

Demircan D, Candan A. Identification of Vibrio anguillarum by PCR (rpoN Gene) associated with Vibriosis in marine fish in Turkey. Turk J Vet Anim Sci. 2006; 30:305-10.

Deng Y, Yang G, Yue J, Qian B, Liu Z, Wang D, Zhao Y. Influence of ripening stages and extracting solvents on the polyphenolic compounds, antimicrobial and antioxidant activities of blueberry leaf extracts. Food Control. 2014;38:184-91.

Drewhurst I. EQ. JMPR Evaluations 1998 Part II Toxicological. Joint meeting of the FAO panel of experts on pesticide residues in food and the environment and the WHO Core Assessment Group, Rome.1998. p. 21-30.

Ekwenye UN, Elegalam NN. Antibacterial activity of ginger (Zingiber officinale Roscoe) and garlic (Allium sativum L.) extracts on Escherichia coli and Salmonella typhi. Int J Mol Med Adv Sci. 2005;1:411-6.

FAO, 1970. PL: 1969/M/17/1, WHO/FOOD/70.38. Pesticide residues in food. Report of the 1969 joint meeting of the FAO working party of experts on pesticide residues and WHO expert group on pesticide residues, FAO Agricultural Studies, No. 84 WHO Technical Report Series, No. 458, 159 EQ, Rome.

Gabor E, Sara A, Barbu A. The effects of some phytoadditives on growth, health and meat quality on different species of fish. Anim Sci Biotechnol. 2010;43:61-5.

Hassanin ME, Hakim Y, Badawi ME. Dietary effect of ginger (Zingiber officinale Roscoe) on growth performance, immune response of Nile tilapia (Oreochromis niloticus) and disease resistance against Aeromonas hydrophila. Abbassa. Int J Aquac. 2014;7:35-52.

Hwang J, Lee S, Rha S, Yoon H, Park E, Han K, Kim S. Dietary green tea extract improves growth performance, body composition, and stress recovery in the juvenile black rockfish. Sebastes schlegeli. Aquac Int. 2013;21:525-38.

Jeon GH, Kim HS, Myung SH, Cho SH. The effects of the dietary substitution of fishmeal with tuna by-product meal on growth, body composition, plasma chemistry and amino acid profiles of juvenile Korean rockfish (Sebastes schelgeli). Aquac Nutr. 2014;20:753-61.

Ji SC, Jeong G, Im GS, Lee SW, Yoo JH, Takii K. Dietary medicinal herbs improve growth performance, fatty acid utilization, and stress recovery of Japanese flounder. Fish Sci. 2007b:73:70-6.

Ji SC, Takaoka O, Jeong GS, Lee SW, Ishimaru K, Seoka M, Takii K. Dietary medicinal herbs improve growth and some non-specific immunity of red sea bream Pagrus major. Fish Sci. 2007a;73:63-9.

Jung $\mathrm{SH}$, Choi H, Do J, Kim MS, Kwon M, Seo JS, Kim JW. Monitoring of bacteria and parasites in cultured olive flounder, black rockfish, red sea bream and shrimp during summer period in Korea from 2007 to 2011. J Fish Pathol. 2012;25:231-41.

Kent ML, Poppe $\Pi$. Infectious diseases of cold water fish in marine and brackish water. In: Woo PTK, Bruno DW, Lim LHS, editors. Diseases and Disorders of Finfish in Cage Culture. CAB International Publishing: Wallingford; 2002. p. 61-105.

Kim HS, Kim HJ, Choi DG, Jang B, Cho SH, Kwon M, Kim DS. Effect of various source of dietary additives on growth, body composition, and challenge test survival of juvenile rockfish Sebastes schlegeli. Turk J Fish Aquat Sci. 2016;16: 759-66.

Kim K, Wang X, Han K, Bai SC. Optimum dietary protein level and protein-toenergy ratio for growth of juvenile Korean rockfish Sebastes schlegeli. J World Aquac Soc. 2004;35:305-14.

Kim K, Wang XJ, Bai SC. Reevaluation of the optimum dietary protein level for the maximum growth of juvenile Korean rockfish, Sebastes schlgeli (Hilgendorf). Aquacult Res. 2001:32:119-25.

Kim KH, Hwang YJ, Bai SC. Resistance to Vibrio alginolyticus in juvenile rockfish (Sebastes schlegeli) fed diets containing different doses of aloe. Aquaculture. 1999;180:13-21. 
Kim S, Harikrishnan R, Kim M, Balasundaram C, Heo M. Broussonetia kazinoki as a feed additive enhances disease resistance against Streoptococcus parauberis in Paralichthys olivaceus. Fish Pathol. 2012;47:20-2.

Lee $\mathrm{S}$, Hwang U, Cho SH. Effects of feeding frequency and dietary moisture content on growth, body composition and gastric evacuation of juvenile Korean rockfish (Sebastes schlegeli). Aquaculture. 2000;187:399-409.

Lee S, Jeon IG, Lee JY. Effects of digestible protein and lipid levels in practical diets on growth, protein utilization and body composition of juvenile rockfish (Sebastes schlegeli). Aquaculture. 2002;211:227-39.

Lee S, Kim K. Effects of dietary carbohydrate to lipid ratios on growth and body composition of juvenile and grower rockfish. Sebastes schlegeli. Aquacult Res. 2009;40:1830-7.

Lee S, Yoo J, Lee JY. The use of soybean meal, corn gluten meal, meat meal, meat and bone meal, or blood meal as a dietary protein source replacing fish meal in Korean rockfish (Sebastes schlegeli). Korea J Anim Nutr Feedstuffs. 1996;20:21-30.

Lee SM. Review of the lipid and essential fatty acid requirements of rockfish (Sebastes schlegeli). Aquacult Res. 2001;32:8-17.

Li J, Gao D, Wang Q, Wang J, Wang Q. Efficacy of Vibrio anguillarum antigen administered by intraperitoneal injection route in Japanese flounder, Paralichthys olivaceus (Temminck et Schlegel). Aquacult Res. 2005;36:1104-11

Lim DK, Yoo KY, Shin DG, Kim JE, Bae J, Bai SC, Lee JY. Effects of dietary kugija Lycium chinense supplementation on juvenile Korean rockfish Sebastes schlegeli. Korean J Fish Aquat Sci. 2009;42:250-6.

Lim SR, Choi SM, Wang XJ, Kim KW, Shin IS, Min TS, Bai SC. Effects of dehulled soybean meal as a fish meal replacer in diets for fingerling and growing Korean rockfish Sebastes schlegeli. Aquaculture. 2004;231:457-68.

Mizanur RM, Yun H, Moniruzzaman M, Ferreira F, Kim K, Bai SC. Effects of feeding rate and water temperature on growth and body composition of juvenile Korean rockfish, Sebastes schlegeli (Hilgendorf 1880). Asian-Australa J Anim Sci. 2014;27:690-9.

Molan AL, Lila MA, Mawson J. Satiety in rats following blueberry extract consumption induced by appetite-suppressing mechanisms unrelated to in vitro or in vivo antioxidant capacity. Food Chem. 2008;107:1039-44.

Nya EJ, Austin B. Use of dietary ginger, Zingiber officinale Roscoe, as an immunostimulant to control Aeromonas hydrophila infections in rainbow trout, Oncorhynchus mykiss (Walbaum). J Fish Dis. 2009;32:971-7.

Papandreou MA, Dimakopoulou A, Linardaki ZI, Cordopatis P, Klimis-Zacas D, Margarity M, Lamari FN. Effect of a polyphenol-rich wild blueberry extract on cognitive performance of mice, brain antioxidant markers and actylcholinesterase activity. Behav Brain Res. 2009;198:352-8.

Park JS, Kim HS, Chin KB. The antioxidant activity of yacon (Polymnia sonchifolia) and its application to the pork patties as a natural antioxidant. Korean J Food Sci Anim Resour. 2012;32:190-7.

Punitha SMJ, Babu MM, Sivaram V, Shankar VS, Dhas SA, Mahesh TC, Citarasu T. Immunostimulating influence of herbal biomedicines on non-specific immunity in grouper Epinephelus tauvina juvenile against Vibrio harveyi infection. Aquac Int. 2008;16:511-23.

Sebiomo A, Awofodu AD, Awosanya AO, Awotona FE, Ajayi AJ. Comparative studies of antibacterial effect of some antibiotics and ginger (Zingiber officinale) on two pathogenic bacterial. J Microbiol Antimicrob. 2011;3:18-22.

Seo J, Kim K, Lee S. Effects of supplemental herb medicines in the diets on growth, feed utilization and body composition of juvenile and grower rockfish Sebastes schlegeli. J Aquaculture. 2009;22:112-7.

Sivaram V, Babu MM, Immanuel G, Murugadass S, Citarasu T, Marian MP. Growth and immune response of juvenile greasy groupers (Epinephelus tauvina) fed with herbal antibacterial active principle supplemented diets against Vibrio harveyi infections. Aquaculture. 2004;237:9-20.

Talpur AD. Mentha piperita (Peppermint) as feed additive enhanced growth performance, survival, immune response and disease resistance of Asian seabass, Lates calcarifer (Bloch) against Vibrio harveyi infection. Aquaculture. 2014:420:71-8

Talpur AD, Ikhwanuddin M. Dietary effects of garlic (Allium sativum) on haematoimmunological parameters, survival, growth, and disease resistance against Vibrio harveyi infection in Asian seabass, Lates calcarifer (Bloch). Aquaculture. 2012;364:6-12.

Talpur AD, Ikhwanuddin M, Bolong AA. Nutritional effects of ginger (Zingiber officinale Roscoe) on immune response of Asian sea bass, Lates calcarifer (Bloch) and disease resistance against Vibrio harveyi. Aquaculture. 2013:400: 46-52.
Tang S, Kerry JP, Sheehan D, Buckley DJ. A comparative study of tea catechins and a-tocopherol as antioxidants in cooked beef and chicken meat. Eur Food Res Technol. 2001;213:286-9.

Thorisson S, Gunstone FD, Hardy R. The antioxidant properties of EQ and of some of its oxidation products in fish oil and meal. J Am Oil Chem Soc. 1992;69:806-9.

Vallejos-Vidal E, Reyes-López F, Teles M, MacKenzie S. The response of fish to immunostimulant diets. Fish Shellfish Immunol. 2016;56:34-69.

Vizzotto M, da Rosa FM, Corbelini DD, Pereira MC, Gonzales TN. Bioactive compounds and antioxidant activity of blueberry (Vaccinium ashei Reade). Acta Hortic. 2013;972:111-6.

Wang J, Ai Q, Mai K, Xu H, Zuo R, Xu W, Zhang C. Effects of dietary ethoxyquin on growth, feed utilization and residue in the muscle of juvenile Japanese seabass. Lateolabrax japonicus. Aquacult Res. 2015;46:2656-64.

Wang J, Ai Q, Mai K, Xu W, Xu H, Zhang W, Liufu Z. Effects of dietary ethoxyquin on growth performance and body composition of large yellow croaker Pseudosciaena crocea. Aquaculture. 2010;306:80-4.

Weil JT, Van der Veen J, Olcott HS. Stable nitroxides as lipid antioxidants. Nature. 1968:219:168-9.

Yan Q, Xie S, Zhu X, Lei W, Yang Y. Dietary methionine requirement for juvenile rockfish. Sebastes schlegeli. Aquac Nutr. 2007;13:163-9.

Yun A, Kim HS, Seo Y, Cho SH, Bae JY. Effects of dietary antioxidant supplementation on the growth, serum chemistry, body composition and challenge test results of juvenile rockfish Sebastes schlegeli. Kor J Fish Aquat Sci. 2016:49:323-9.

\section{Publisher's Note}

Springer Nature remains neutral with regard to jurisdictional claims in published maps and institutional affiliations.
Ready to submit your research? Choose BMC and benefit from:

- fast, convenient online submission

- thorough peer review by experienced researchers in your field

- rapid publication on acceptance

- support for research data, including large and complex data types

- gold Open Access which fosters wider collaboration and increased citations

- maximum visibility for your research: over $100 \mathrm{M}$ website views per year

At BMC, research is always in progress.

Learn more biomedcentral.com/submissions 